\title{
Prevalence and Predictors of Gastrointestinal Parasitic infection among Agro-Pastoral Cattle Herds in Ibarapa, Oyo State, southwestern Nigeria
}

\author{
Olubukola Adelakun ${ }^{1}$, Foluke Akande ${ }^{2}$, Joseph Olumoyegun ${ }^{3}$, Emmanuel Awosanya ${ }^{3}$, \\ Olayinka Ishola ${ }^{3}$, and Simeon Cadmus ${ }^{3}$ \\ ${ }^{1}$ Affiliation not available \\ ${ }^{2}$ Federal University of Agriculture Abeokuta \\ ${ }^{3}$ University of Ibadan
}

April 28, 2020

\begin{abstract}
Gastrointestinal parasites (GIP) are a major setback to profitable cattle production in developing countries like Nigeria. However, despite the huge population of pastoralists and their cattle in Ibarapa Area, Nigeria, there is limited information on the prevalence of GIP among the resident cattle. This study was therefore carried out to determine the prevalence, distribution and factors associated with GIP among agro-pastoral cattle herds. Here, we carried out a cross-sectional study to screen different cattle herds for GIP between May and August 2019 in the Ibarapa Area of Oyo State, southwestern Nigeria. Faecal samples were obtained from randomly selected cattle and examined for GIP ova and oocysts using salt/ sugar centrifugal floatation technique at a specific gravity of 1.3. Factors such as breed, sex, age, body condition score (BCS) and herd size were obtained. Descriptive statistics and odds ratios (OR) were calculated. Chi-square test was used to determine the level of significance at a $95 \%$ confidence interval (95\% CI). Predictors of GIP presence were determined using logistic regression. A total of 377 cattle comprising of 347 females from 39 different cattle herds, with age range 1 year to 15 years were screened. An overall prevalence of $58.1 \%$ (219) was obtained for cattle having at least one GIP. Eimeria spp had the highest prevalence (41.1\%) followed by Neoascaris spp (10.1\%), Strongyles spp (8.0\%), Taenid spp (7.7\%), Paraphistomum spp (6.1\%), Monienza spp $(2.9 \%)$, Nematodirus spp (2.9\%), Schistosoma spp (2.7\%) and Strongyloides spp $(2.1 \%)$. Predictors of GIP infection were age $(\mathrm{OR}=0.5$; CI: $0.3-0.8)$, BCS $(\mathrm{OR}=2.3$; CI: $1.5-3.7)$, breed $(\mathrm{OR}=0.5$; CI: $0.3-0.7)$ and herd size $(\mathrm{OR}=0.6$; CI: $0.4-$ 0.8). High prevalence of GIP among agro-pastoralist cattle herds' calls for improved animal health care delivery and assess to veterinary services among this population.
\end{abstract}

\section{INTRODUCTION}

The livestock production sector in Nigeria contributes immensely to the economic well-being of the nation and over $80 \%$ of the population are in a way involved in agriculture (Otuma and Udenwa, 2009). Cattle production contributes $50 \%$ of the total meat supplied by the livestock industry in Nigeria (Adedipe et al., 1996). The cattle population in Nigeria has been estimated to be 15.3 million (Umar, 2007; Umar et al., 2008; Tibi and Aphunu, 2010) with $80 \%$ of this managed by the pastoralists (Okoli et al., 2012) who practice extensive production system which is the traditional method of grazing cattle in Africa (Kanyari et al., 2009). Breeds of cattle indigenous to Nigeria are the White Fulani, Red Bororo, Sokoto Gudali (Bokolo), Adamawa Gudali, Wadara, Azawak, Muturu, Keteku, Ndama and Kuri (Pagot, 1992; Babayemi et al., 2014). However, the popular breeds of cattle in southwestern Nigeria are mainly White Fulani and the Bokolo breeds.

Gastrointestinal parasitism is mainly caused by helminths and protozoa (Williams and Loyacano, 2012). Three major classes of helminths that are of veterinary importance often affect the gastrointestinal tract 
of cattle. They include the nematodes (e.g. Nematodiru s sp, Ascaris sp, Strogyloides sp), trematodes (e.g.Paraphistomum sp, Schistosomum sp) and cestode (e.g.Monienzia sp ) (Onaga et al., 2009). Geoclimatic conditions and a poor GIP awareness by livestock farmers contribute towards a conducive environment for the development and growth of parasites (Raza et al., 2007). Some gastrointestinal parasites (GIP) of cattle likeShistosomum sp and Fasciola sp have potentials of infecting humans (Oslo and Guselle, 2000) and the increasing resistance of GIP to several anti-helminthics (Jackson and Coop, 2000; Albonico, 2003; Albonico et al., 2004) are major challenges that require swift solutions. Notably, the increasing gastrointestinal helminth infections in cattle due to continuous re-infection from persistent exposures to infected grazing lands has a way of aggravating the challenge of helminths' resistance to dewormers.

The traditional method of grazing cattle in Nigeria predisposes them to ingest infective stages of GIP during grazing and/or use of communal water sources. Of the three gastrointestinal helminths classes of veterinary importance, the nematodes are responsible for the most economically devastating effect of livestock in Nigeria (Afolabi et al., 2017). This is aided when grazing animals ingest infective larvae from the pasture, the larva develops into adult parasites in their host and lays eggs, which are excreted in the ruminant faeces. The life cycle continues when the eggs hatch and larvae develop on pasture, where they can be ingested by grazing ruminants (Blackburn et al., 2011). The trematodes are equally important but will only thrive amidst intermediate host and in areas with poorly drained pastures and stagnant water. Cestodes, on the other hand, have less impact on cattle performance when compared with nematodes and trematodes (Shane et al., 2015). The typical lifecycle is also indirect, requiring one or more intermediate host. Gastrointestinal parasites, a major constraint to cattle production, are found within the gastrointestinal tract (GIT) of the animals (Oluwafemi, 2008). They constitute an impediment to efficient and profitable livestock production (Joachim et al.,2001). Gastrointestinal parasites might cause a wide range of health problems ranging from subclinical disease to actual death, depending primarily on the parasitic load and the general health of the animal (Schutz et al., 2012). Importantly, impaired reproductive performance has also been demonstrated because of the parasite burden (Forbes et al., 2004; Szyszka et al., 2013). Further, gastrointestinal parasites generate increased losses of endogenous protein, which might be a potential cause of the reduced weight gain in infected cattle (Kyriazakis et al., 1998).

Although studies have been conducted on GIP of cattle in various localities in Nigeria (Pam et al 2013; Sylvia et al., 2015; Okike-Osisiogu et al., 2016; Takeet et al., 2016; Abah and Ebong, 2017; Afolabi et al., 2017; Adelakun and Akande, 2018), little information is available regarding the gastrointestinal parasitic infections in Ibarapa Central and North Local Government Areas (LGAs) in Oyo State. This study area provides good arable land for pasture, which is attractive to pastoralists and farmers, which are the primary inhabitants of the area. The study was designed to investigate and provide additional information on the prevalence, distribution and factors associated with gastrointestinal parasites in agro-pastoral cattle herds in Ibarapa Central and North LGAs of Oyo State, Nigeria.

\section{MATERIALS AND METHODS}

\subsection{Study location}

The Ibarapa area is divided into three LGAs by the Federal Government of Nigeria in 1996 with an estimated human population of about 322,295 by the National Population Census of 2006. The Ibarapa area is located approximately 100 kilometres north of the coast of Lagos and about 95 kilometres west of Oyo State capital and neighbouring city, Ibadan (Duze, 1984). The landmass of Ibarapa area is approximately 1,600 square kilometres, and the area borders with the rain forest belt to the south but consists of rolling savannah with residual patches of forest growing near watercourses. Most of the land lies between 400 to 600 feet above sea level, but rocky outcrops rising to 1,000 feet occur within the setting, adding to the natural beauty of the landscape (Ogunlesi et al., 1989). The area provides good arable land for animal pasture and agricultural production which is the major occupation of members of the community and the attractive force keeping the residing pastoralists in the land. The Ibarapa area can confidently boast of over 10 thousand heads of cattle. In addition to the rearing of cattle, agro-pastoralist also plant crops like yam, maize and millet for subsistence. They tether their cattle in open kraals that are not too far away from their homestead. During 
the dry season, they become transhumant because they travel far with their herds in search of lush pasture for their cattle to graze, to return home when the rain starts.

\subsection{Study population}

The study population were cattle herds managed extensively by agro-pastoralists in the study location.

\subsection{Study design}

A cross-sectional study was conducted in two (2) LGAs; Ibarapa Central and Ibarapa North in Oyo State, southwestern Nigeria between May and August 2019.

\subsection{Sample size and sampling}

The minimum sample size (n) required was determined according to Thrusfield (2007) using 95\% level of confidence, the prevalence of $66.1 \%$ (Adelakun and Akande, 2018) and desired absolute precision of 5\%. i.e. $\mathrm{n}=\mathrm{Z}^{2} \mathrm{p}(1-\mathrm{p}) / \mathrm{d}^{2}=345$ cattle. However, 377 cattle were examined to increase precision.

Cattle were selected randomly from 39 different herds across the two LGAs, the herds were grouped into three; 0-30, 31-50 and $>50$ based on the herd size. The average number of cattle per herd is 48 , an average of $20 \%$ of each herd was sampled. The maximum herd size screened was 89 while the least sampled was 29 .

\subsection{Data and sample collection}

Data on the age, sex, breed, body condition score and herd size were collected. The age was grouped into $<2,3-5$ and $>$ 5years according to Yugudu et al., 2018. Male and female cattle were randomly selected without any preference. The breeds of cattle sampled included White Fulani, Bokolo and Crossbreed. The body condition was scored as lean, moderate and good as previously described by Adedipe et al. (2014). Faecal samples were collected directly from the rectum into properly labelled sterile universal bottles. The faecal samples were kept in a cool box with ice packs after collection and during transport to the laboratory.

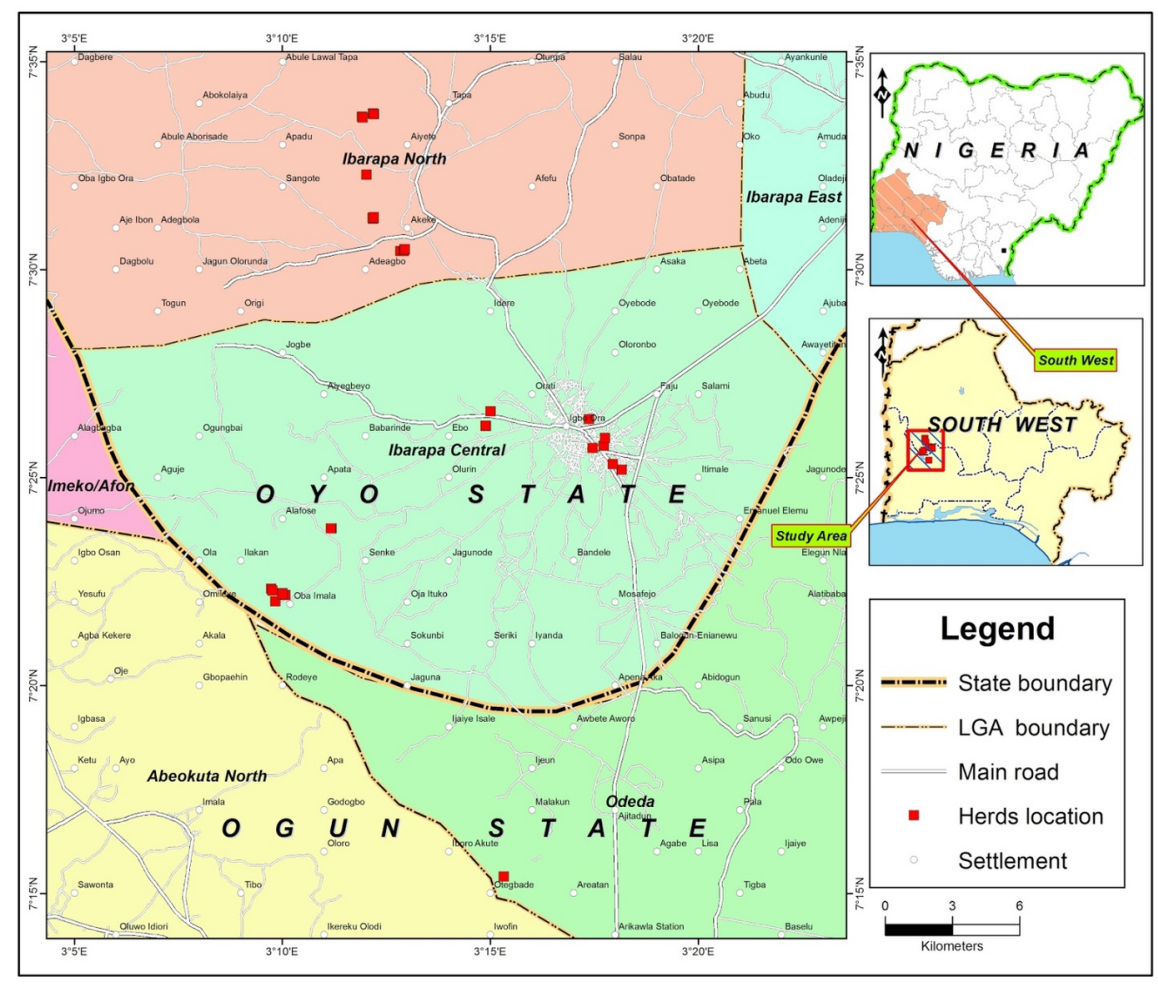


Figure 1: Map of the study area.

\subsection{Parasitological procedure}

The faecal samples were processed at the Parasitology Laboratory, Department of Veterinary Microbiology and Parasitology, Federal University of Agriculture, Abeokuta, Nigeria. Faecal samples were examined for GIP ova and oocysts using centrifugal floatation techniques. Salt/sugar solution at a specific gravity of $1.3 \mathrm{~g}$ was used as the floatation solution (www.rcv.ac.uk/review/Parasitology/Flotation fluid/General.htm accessed 26/04/2017). Identification of ova and oocysts was made according to the description given by MAFF (1979) and Soulsby (1982). A positive cattle herd is any herd with the presence of one or more GIPs in the faecal samples.

\subsection{Data analysis}

Data were analyzed using IBM Statistical Package for Social Sciences (SPSS) software package version 23 and Epi-Info version 3.5.1. Descriptive statistics such as frequencies and percentages were determined. Association between categorical variables and the outcome variable was assessed by calculating the odds ratios (OR). Chi-square $\left(\chi^{2}\right)$ test was used to determine statistical significance. A multivariable logistic regression model was used to determine predictors of GIP infection while adjusting for other covariates that were significant at $\mathrm{p}<0.10$ in the bivariate analysis. The best fit model was selected based on the Likelihood Ratio. Adjusted odds ratios (AOR) and $95 \%$ Confidence Interval (95\%CI) were reported. The level of significance was at $5 \%$.

\subsection{Ethical consideration}

The authors which to state that the ethical policies of the journal, as obtained on the journal's author guidelines page, were duly followed and adhered to and the appropriate ethical review committee approval was obtained. Importantly, this research was approved by the Animal Care and Use Research Ethics Committee of the University of Ibadan, Nigeria, before the commencement of the study (UI-ACUREC/17/0101). Further, following accepted community entry approach (i.e. going through stakeholders' meeting with the hierarchy and members of the pastoralists' community) as well as education of the pastoralists on the project, verbal approval was provided by all the herders. Lastly, for study participation, informed consent was obtained from the representative/head of cattle herd owners/pastoralists.

Data Sharing: The data that support the findings of this study are available from the corresponding author upon reasonable request.

\section{RESULTS}

\subsection{Demographic characteristics of the sampled cattle}

Of the 377 cattle screened, most 329 (87.3\%) were of the White Fulani breed, while the least was Bokolo $(4.8 \%)$. The majority $(92 \%)$ of the cattle were female. The most $(44.8 \%)$ age-group was $>5 y e a r s$ and the least $(11.1 \%)$ was [?] 2 years. Most $(66.6 \%)$ of the cattle screened had good body condition score (BCS) while very few $(3.5 \%)$ were lean. Most of the herd size (56.4\%) were in the category of 31-50 heads group, while the least (183\%) was from the 0-30 group (Table 1).

\subsection{Prevalence of GIP infections}

Of the 377 faecal samples from the 39 agro-pastoral cattle herds screened, 36 cattle herds were positive for one or more GIPs, indicating a herd-level prevalence of $92.3 \%$ for GIP. At the individual animal level, $219(58.1 \%)$ cattle were positive for GIP: helminths $(124 ; 32.9 \%)$, protozoa: $(157 ; 41.6 \%)$, co-infection with helminths and protozoa: $(63 ; 16.7 \%)$ (Table 2$)$.

Nine different genera of parasites were identified: four nematodes, two trematodes, two cestodes and a protozoan. Eimeria spp, the only protozoan identified, had the highest prevalence $(155,41.1 \%)$, followed by Neoascaris spp (38,10.1\%), Strongyles spp (30, 8.0\%), Taenid spp (29, 7.7\%), Paraphistomum spp (23, 
6.1\%), Monienza spp (11, 2.9\%), Nematodirus spp (11, 2.9\%), Schistosoma spp (10, 2.7\%) and Strongyloides spp, a helminth that had the least prevalence of $2.1 \%$, were identified (Table 2).

\subsection{Demographic factors associated with GIP infection}

Of the 377 cattle sampled, the White Fulani breed had the highest GIP presence of $67 \%$, while the least $(22.2 \%)$ was in Bokolo. We observed a significant association between the White Fulani breed of cattle and GIP infection compared to the Bokolo (OR: 0.2; 95\% CI: $0.04-0.6$ ) and other crossbreeds (OR: 0.2; 95\% CI: $0.1-0.5)$. The presence of GIP was highest $(76.2 \%)$ in age group [?] 2 years, with the least $(53.3 \%)$ in the age group $>5$ years' cattle. A significant association existed between older cattle aged greater than 5 years and GIP infection (OR: 0.4; 95\% CI: 0.2 - 0.8) compared to those 2 years and below. Also, we observed a significant association between age group 3-5 years and GIP infection (OR: 0.4; 95\% CI: 0.2 - 1.0) when compared with those 2 years and below. Cattle with lean BCS had the highest (92.3\%) presence of GIP, and the least $(38.1 \%)$ was in cattle with the moderate condition. Cattle with moderate body condition score were less likely to have GIP infection when compared to the lean cattle (OR: 0.1; 95\% CI: $0.001-0.4$ ). Cattle from herds numbering between one to 30 (1-30) had the highest (85.7\%) GIP infection, while those from herds with 31 to 50 cattle had the least $(50.2 \%)$. There was a significant association between cattle from herd size 1 to 30 and GIP infection compared to those from 31 to 50 (OR: 0.2; 95\% CI: $0.1-0.4$ ) and those with greater than 50 cattle (OR: 0.2; 95\% CI: 0.1-0.6). Gastrointestinal parasite infection was higher among female $(58.2 \%)$ than male $(56.7 \%)$ cattle. Sex, however, was not significantly associated with GIP infection (Table 3). A statistically significant association was observed between age and the prevalence of Neoascaris spp (OR: 2.3; 95\% CI: 0.9-6.2), Taeni d egg (OR: 6; 95\% CI: 1.7-32.14) and Eimeria spp (OR: 2.4; 95\% CI: 1.4-4.3). There was a significant association between the breed of cattle and Eimeriaspp (OR: 4.0; 95\% CI: 1.1-22.1). BCS was also significantly associated with the prevalence of Eimeria spp (OR: 0.2; 95\% CI: 0.03-0.6) (Tables $4-7$ ).

On multivariable logistic regression, age (aOR: $0.5 ; 95 \%$ CI: $0.3-0.8$ ), BCS (aOR: $2.3 ; 95 \%$ CI: $1.5-3.7$ ), breed (aOR: $0.5 ; 95 \%$ CI: $0.3-0.7$ ) and herd size (aOR: 0.6; 95\%CI: $0.4-0.8$ ) remained predictors of GIP infection (Table 8).

\section{DISCUSSION}

The overall individual prevalence and herd prevalence of GIP infection reported among agro-pastoral cattle herds in this study were $58.6 \%$ and $92.3 \%$, respectively. The high GIP infection is a reflection of the extent of contamination of the grazing paddock or pasture with infective stages of these parasites (Fikru et al., 2006). This could be as a result of the traditional husbandry method used in rearing the cattle (Adejinmi and Harrison, 1997). Reports from different parts of Nigeria also showed the prevalence of GIP ranging from 34.9\% to 82.24\% (Afolabi et al., 2007; Pam et al., 2013; Sylvia et al., 2015; Okike-Osisiogu et al., 2016; Takeet et al., 2016; Abah and Ebong, 2017; Adelakun and Akande, 2018). High prevalence rates of GIP have also been reported from other countries including Colombian Northeastern Mountain (50.5\%) (Pinilla León et al., 2019), Pakistan (64.6\%) (Rafiullah et al., 2011) and Ghana (95.5\%) (Squire et al., 2013). The prevalence reported in this study is an indication that GIP infection remains a threat to the livestock industry because of its ability to cause a reduction in weight gain, high morbidity and mortality especially in young animals (Diaz de Ramírez et al., 1998; Cordero and Rojas, 1999).

Notably, Eimeria spp was the only protozoan and most abundant GIP identified in this study. Contamination of water and pasture by excretion and secretion from infected cattle as well as poor pasture management (Tamasaukas et al., 2010) are factors that could contribute to the high prevalence. The parasitic abundance of Eimeria spp corroborates earlier finding from the study location where a prevalence of $40.1 \%$ was reported (Adelakun and Akande, 2018). In contrast, Karaye et al. (2018) reported a much lower prevalence of Eimeria spp in Plateau State. This study also negates previous reports by Raza et al. (2014) and Swarnakar et al. (2015) that coccidian oocysts were the least GIP observed. The variation in prevalence could be due to immunological status and management condition. Eimeria spp are known to cause coccidiosis primarily in calves and accompanying signs are diarrhoea, dehydration, weight loss, depression, loss of appetite and 
occasionally, death may also be observed in infected animals (Squire, 2013).

The nematodes recorded the highest prevalence of GI helminths, which agrees with other previous studies (Tshering and Dorji 2013; Adelakun and Akande, 2018). Death of livestock is common in the tropics where marginal levels of nutrition exacerbate the detrimental effects of infection (Ademola and Eloff, 2010). Most prevalent nematode identified in this study was Neoascaris vitulorum ; previous study by Raza et al. (2007) in Pakistan has also shown $N$. vitulorum to be the most frequently occurring nematode in cattle. The prevalence obtained in this study is similar to the $10.2 \%$ reported in Oyo State by Oluwole et al. (2016). Neoascaris vitulorum is a parasite of the small intestine of ruminants (Roberts, 1990). It is responsible for high morbidity and mortality rates in ruminants (Das and Singh, 1955; Patnaik and Pande, 1963) resulting in serious economic losses (Enyenihi, 1969).

Other nematodes identified include Strongyles spp,Nematodirus spp and Strongyloides spp. Schistosomaspp and Paramphistomum spp belong to the trematoda class and are both helminths of veterinary importance. They are responsible for schistosomosis and paramphistomosis, respectively. Schistosomaspp however, is of public health importance as the report of hybrid ofS. bovis and S. haematobium (Webster et al., 2013) are been reported in Africa. The prevalence observed could be as a result of the rainy season during which the study was carried out. This could have aided the viability of eggs, growth and development of both the infective stages of the parasites and the intermediate host, all of which are necessary for the successful completion of the parasite's indirect life cycle (Colina et al., 2013).

Taenid spp and Monienza spp were the only two identified cestode species. The Taenid spp have zoonotic implication. Cattle are the known intermediate hosts while humans are the definitive hosts. However, in this study, we found eggs typical of Taenia, which suggests the need for further studies; particularly molecular characterization towards deciphering the true picture of things. Monienza spp is responsible for monieziasis which is often present in ruminants that graze on infected pastures and the infection is maintained by the availability of Oribatid mites (intermediate hosts) that are required for the completion of the lifecycle of Moniezia spp (Quiroz et al., 2011).

Generally, susceptibility to GIP infection might be influenced by varying factors such as age, breed, health status, pregnancy and history of early infection (Pfukenyi and Mukaratirwa, 2013). However, in this study, age, BCS, breed and herd size were the factors significantly associated with the prevalence of GIP. A relatively high GIP infection was observed in cattle $<2$ years of age compared to the young and adult cattle. This age prevalence of GIP is similar to the findings of Tilak et al. (2016). The higher GIP infection in cattle less than 2 years could be because the older cattle, greater than 2years, are more resistant to GIP, while the cattle $<2$ years are more susceptible to infection (Pfukenyi et al., 2007), being new and just coming to the pasture. Cattle with lean BCS had the highest GIP infection, a likely impact of GI parasites on the body mass of severely affected cattle. Insufficient fat reserves, poor health and nutritional factors are primary reasons why poorly conditioned animals are weak at mounting protective immunity against worm infestation (Tasawar et al., 2011). The White Fulani breed of cattle had the highest GIP infection, an outcome that corroborates previous studies in Adamawa State (Aliyara et al., 2012; Qadeer et al., 2015). This may simply be because it was the predominant breed sampled. Finally, cattle from herd size that were grouped into 1-30 had GIP prevalence higher than other groups of 31-50 cattle and the greater than 50 . The association of herd size to GIP prevalence might be as a result of the immunological status of the animals, difference in the grazing area and management conditions (Regassa et al., 2006).

\section{CONCLUSION}

In conclusion, the present study shows that agro-pastoral cattle in Ibarapa Central and North Areas of Oyo State, southwestern Nigeria are heavily infected with GIP. This implies that GIP are still a threat to profitable cattle production in Ibarapa. Importantly, some of the parasites identified in this study, like Schistosoma spp and Taenia spp are of zoonotic importance, which further gives credence for the need to curtail GIP amongst livestock to promote public health. Additionally, this study shows that age, breed, BCS and herd size are important predictors of GIP infection. Finally, the effective control of GIP infection 
in cattle herds in this area and similar settings in Nigeria and Africa with the use of drugs and improved husbandry practices are recommended.

\section{ACKNOWLEDGEMENTS}

We would like to thank the herd owners for their cooperation and assistance in the restraint of the cattle for examination and sample collection.

\section{CONFLICT OF INTEREST}

The authors declare that they have no competing interests.

\section{References}

Abah, A.E., \& Ebong, N.E. (2017). Survey of Gastrointestinal Parasite of Cattle and Goat

Slaughtered At Trans Amadi Abattoir, Port Harcourt-Rivers State.IOSR Journal of Pharmacy and Biological Sciences, 12 (3), 21-24.

Adedipe, O.D., Uwalaka, E.C., Akinseye, V.O, Adediran, O.A., \& Cadmus, S.I. (2014).

Gastrointestinal helminths in slaughtered cattle in Ibadan, south-Western Nigeria. Journal of Veterinary Medicine. http://dx.doi.org/10.1155/2014/923561

Adedipe, N. O., Bakshi, J. S., Odegbaro, O. A., \& Aliyu, A. (1996).

Evolving Nigeria

Agricultural Research Strategy Plan:Agro-Ecological Inputs, National Agricultural Research Project (NARP).

Adelakun, O.D., \& Akande, F.A.(2018). Assessment of gastrointestinal parasites in extensively grazed cattle in southwestern Nigeria. Journal of Animal Health and Production, Africa, 66

(4), 741-749.

Adejinmi J.O., \& Harrison L.J.S. (1997). Parasitic nematodes of domestic ruminants in Nigeria: impact on ruminant production and control. Tropical Veterinarian , 15, 137-148.

Ademola, I. O., \& Eloff, J. N. (2010). In vitro anthelmintic activity of Combretum molle (R.Br.

ex G. Don) (Combretaceae) against Haemonchus contortus ova and larvae, Veterinary Parasitology, 169, 198-203. https://doi.org/10.1016/j.vetpar.2009.12.036

Afolabi, O.J., Simon-Oke, I.A., \& Ademiloye, A.O. (2017). Gastro-intestinal parasites of Bovine in Akure abattoirs, Nigeria. Journal of Entomology and Zoology Studies , 5(5), 1381-1384

Albonico, M., Engels, D., \& Savioli, L. (2004). Monitoring drug efficacy and early detection of drug resistance in human soil-transmitted nematodes: A pressing public health agenda for helminth control. International Journal of Parasitology, 34, 1205-1210. https://doi.org/10.1016/j.ijpara.2004.08.001

Albonico, M. (2003). Methods to sustain drug efficacy in helminth control programmes. Acta

Tropica, 86(3), 233-42. https://doi.org/10.1016/S0001-706X(03)00043-3

Aliyara, H.Y., Nwosu, C.O., \& Ardo, M.B. 2012. Prevalence and Seasonal changes on gastrointestinal helminths of Nigerian cattle. Veterinary Research , 5(3), 46-49.

Babayemi, O. J., Abu, O. A., \& Opakunbi, A. (2014). Integrated animal husbandry for schools and colleges, First edition. Positive Press Ibadan, Nigeria, 20 - 122. 
Blackburn, H. D., Paiva, S. R., Wildeus, S., Getz, W., Waldron, D., Stobart, R., Bixby, D., Purdy,

P. H., Welsh, C., Spiller, S., \& Brown, M. (2011). Genetic structure and diversity among U. S. sheep breeds:

Identification of the major gene pools. Journal of Animal Science, 89(8),2336-2348. https://doi.org/10.2527/jas.20103354

Colina, J., Mendoza, G., \& Jara, C. (2013). Prevalence and intensity of gastrointestinal

parasitism by 313 nematodes in bovines, Bos taurus, from the Pacanga district (La Libertad, Peru). Revista de investigación científica, 33 (2): 76-83.

Cordero, C.M., \& Rojas, F. (1999). Parasitología Veterinaria. 1st ed. McGraw Hill, España. p323.

Das, K.M., \& Singh, G.B. (1955). Calf ascariasis in India. A nine years' survey with special

reference to Hetrazan. British Veterinary Journal, 111, 342-347. https://doi.org/10.1016/S0007-1935(17)471053

Diaz de Ramírez, A., Justo, J.A., González, M., Piña, E.F., \& Ramírez, L.I. (1998) Prevalence of coccidia in bovines of the plains of Monay, Trujillo state, Venezuela.Revista cientifica de veterinaria. FCVLUZ, 3 (4): 346-353.

Duze, M. (1984). Primary Atlas for the Oyo, Ondo and Ogun States of Nigeria. Ibadan:

Macmillan.

Enyenihi, U.K. (1969). Pathogenicity of Neoascaris vituloruminfection in calves. Bulletin of

Epizootic Diseases, Africa 17, 171-178.

Fikru, R., Teshale, S., Reta, D., \& Yosef, K. (2006). Epidemiology of gastrointestinal parasites of ruminants in Western Oromia, Ethiopia. International Journal of Applied Research in Veterinary Medicine, $4(1), 51-57$

Forbes, A.B., Huckle, C.A., \& Gibb, M.J. (2004). Impact of the epinomectin on grazing behaviour and performance in dairy cattle with sub-clinical gastrointestinal nematode infections under continuous stocking management. Veterinary parasitology, 125, 353-364. https://doi.org/10.1016/j.vetpar.2004.07.025

Jackson, F., \& Coop, R.L. (2000). The development of anthelminthic resistance in sheep nematodes.Parasitology, 120, 95-107.https://doi.org/10.1017/S0031182099005740

Joachim, A., Dulmer, N., Dangschies, A., \& Roepstorff, A. (2001). Occurrence of helminths in pig fattening units with different management systems in Northern Germany, Veterinary Parasitology, 96, 135-146. https://doi.org/10.1016/S0304-4017(00)00431-3

Kanyari, P., Kagira, J., \& Mhoma, R.J. (2009). Prevalence and intensity of endoparasites in small ruminants kept by farmers in Kisumu Municipality, Kenya. Veterinary Parasitology,51(4):137-41.

Karaye, P.G., Ola-Fadunsin, S.D., \& Dogo, G.A. (2018). Diversity of gastrointestinal parasites affecting some domestic animals in Plateau State, North Central Nigeria.

Science World

Journal, 13(1).

Kyriazakis, I., Tolkamp, B.J., \& Hutchings, M.R. (1998). Towards a functional explanation of the occurrence anorexia during parasitic infections. Animal behavior,56, 65-274. https://doi.org/10.1006/anbe.1998.0761 
MAFF. (1979). Parasitological laboratory techniques. Technical Bulletin No. 18. London, HMSO.

Ogunlesi, T.O., Oyediran, A.B., \& Briegar, W.R. (1989). 'Ibarapa, the district and its people in 25 years of the Ibarapa Community Health Programme. African Press Limited

Okike-Osisiogu, F.U., Arinze, A.G., \& Ekaiko, M.U. (2016). Prevalence of intestinal parasite in cattle slaughtered in Aba. International Journal of Research 83 Development Organization.

Okoli, I.C., Enyinnia, N.C., Elijah, A.G, Omede, A.A., \& Unamba-Opara, C.I. (2012). Animal reproductive management practices of Fulani pastoralists in the humid rain Forest of Imo State, Nigeria. Journal of Animal Science Advances, 2(2), 221-225.

Oluwafemi, R.A. (2008). "Gastrointestinal helminthes and public health overview of the neglected sector. International Journal of Veterinary Medicine4(2), 72-78. https://doi.org/10.5580/d1a

Oluwole, A.S., Adeniran, A.A., Mogaji, H.O., Shittu, E.O., Alabi, O. M., Odoemene, S.,\& Ekpo

U.F. (2016). Survey of Gastrointestinal Parasites among Nomadic Cattle Herds in Eruwa, Oyo State, Southwestern Nigeria. Annual Research $\&$ Review in Biology, 10(6), 1-7. https://doi.org/10.9734/ARRB/2016/28400

Onaga, T., Hara, N., \& Shimizu, Y. (2009). Role of nitrergic nerves in the regulation of motility of the omasum and abomasum in healthy sheep (Ovis aries). Veterinary research communications, 33(1), 33-48. https://doi.org/10.5455/jasa.20130226010552

Otuma, M.O., \& Uchewa, E.N. (2009). Evaluation of the Production Characteristics of West

African Dwarf and West African $\times$ Red Sokoto Goats of Nigeria. Proceedings of the 42nd Annual Conference of Agricultural Society of Nigeria (ASN) held at Ebonyi State University Abakaliki, Nigeria. pp. 622-625.

Pagot. J. (1992). Animal production in the tropics and subtropics. Macmillan Press Ltd. London and Basingstoke,

Pam, V.A., Ogbu, K.I., Igeh, C.P., Bot, C.J., \& Vincent, G. (2013). The Occurrence of

Gastrointestinal and Haemo parasites of cattle in Jos of Plateau State, Nigeria. Journal of Animal Science and Advances, 3(2):97-102. https://doi.org/10.5455/jasa.20130226010552

Patnaik, M.M., \& Pande, B.P. (1963). Notes on the helminthic infestations encountered in onemonth-old buffalo calves. Indian Veterinary Journal, 40, 128-133.

Pfukenyi, D.M., \& Mukaratirwa, S. (2013). A review of the epidemiology and control of gastrointestinal nematode infections in cattle in Zimbabwe. Onderstepoort Journal of Veterinary Research, 80(1), 12. https://doi.org/10.4102/ojvr.v80i1.612

Pfukenyi, D. M. Mukaratirwa, S. Willingham, A. L. \& Monrad, J. (2007). "Epidemiological

studies of parasitic gastrointestinal nematodes, cestodes and coccidia infections in cattle in the highveld and lowveld communal grazing areas of Zimbabwe," Onderstepoort Journal of Veterinary Research, 74 (2), 129-142. https://doi.org/10.4102/ojvr.v74i2.132

Pinilla León, J.C., Delgado, N.U., \& Florez, A.A. (2019). Prevalence of gastrointestinal parasites in cattle and sheep in three municipalities in the Colombian Northeastern Mountain, Veterinary World, 12(1), 48-54. https://doi.org/10.14202/vetworld.2019.48-54 
Qadeer, M. A., Gumel, M. A., Chessed, G., Nganjiwa,J. I., Bernard, K., Vandi, P., Hakim, D., \& Fadimatu, U. (2015). A Cross-Sectional Study on the Gastrointestinal and Haemoparasites of Trade Cattle In Girei And Yola North Local Government Areas Of Adamawa State, Nigeria. Journal of Agriculture and Veterinary Science, 8(4):3-5

Quiroz, H., Figueroa, J., Ibarra, F., López, M., editors. (2011). Epidemiología de Enfermedades

Parasitarias en Animales Domésticos. FMVZ UNAM, México. p655.

Rafiullah, A.A., Turi, A.S., Sayyed, R.S., Shabbir, A., \& Muhammad, S. (2011). Prevalence of gastrointestinal tract parasites in Cattle of khyber pakhtunkhwa.ARPN Journal of Agricultural and Biological Science, 6.9.

Raza, M.A., Younas, M., \& Schlecht, E. (2014). Prevalence of gastrointestinal helminths in pastoral sheep and goat flocks in the cholistan desert of Pakistan. The Journal of Animal Es Plant Sciences. 24(1): 127-134.

Raza, M.A., Iqbal, A., Jabbar, A., \& Yaseen, M. (2007). Point prevalence of gastrointestinal helminthiasis in ruminants in southern Punjab, Pakistan. Journal of Helminthology. 81, 323-328. https://doi.org/10.1017/S002

Regassa, F., Sori, T., Dhuguma, R., \& Kiros, Y. (2006). "Epidemiology of gastrointestinal parasites of ruminants in Western Oromia, Ethiopia," International Journal of Applied Research in Veterinary Medicine, 4(1),51.

Roberts, J.A. (1990). The egg production of Toxocara vitulorum in Asian buffalo (Bubalus ubalis). International Journal for Parasitology, 37, 113-120. https://doi.org/10.1016/0304- 4017(90)90066-K Schutz, J.S., Carroll, J.A., Gasbarre, L.C., Shelton, T.A., Nordstrom, S.T., Hutcheson, J.P., Van

Campen, H., \& Engle, T.E. (2012). Effects of the gastrointestinal parasites on parasite burden, rectal temperature, and antibody titer responses to vaccination and infectious bovine rhinotracheitis virus challenge. Journal of Animal Science, 90, 1948-1954. https://doi.org/10.2527/jas.2011-4059

Shane, G., Jodie, P., \& Jeremy, P. (2015). Internal Parasites in Beef and Dairy Cattle. Extension Veterinarian University of Arkansas Division of Agriculture, Cooperative Extension Service.

Soulsby, E.J.L. (1982). Helminthes, arthropod and protozoan of domesticated animals. 7th edition,

Bailliere Tindall: London. UK, 809-810.

Squire, S A, Amafu-Dey, H., \& Beyuo, J. (2013). Epidemiology of gastrointestinal parasites of cattle from selected locations in Southern Ghana. Livestock Research for Rural Development, 25 (7)

Swarnakar, G., Bhardawaj, B., Sanger, B., \& Roat, K. (2015). Prevalence of gastrointestinal parasites in cow and buffalo of Udaipur district, India.International Journal of Current Microbiology and Applied Science, 4(6), 897-902

Sylvia, O.U., Oluwole, A.S., Mogaji, H.O. Adeniran, A.A., Alabi, O.M., \& Ekpo, U. F. (2015).

Livestock Farm in Abeokuta, South-Western Nigeria. Annual Research 86 Review in Biology, 8(4), 1-8.

Szyszka, O., Tolkamp, B.J., Edwards, S.A., \& Kyriazakis, I. (2013). Do the changes in the

behaviours of cattle during parasitism with Ostertagia Ostertagi have a potential diagnostic value? Veterinary Parasitology https://doi.org/10.1016/j.vetpar.2012.10.023 
Takeet, M. I., Badru, O.B., Olubgbogi, E., \& Abakpa, S.A.V. (2016). Prevalence of gastrointestinal parasites of cattle in Abeokuta, Ogun State, Nigeria. Nigerian Journal of Animal Science. $18(2)$

Tamasaukas, R., Agudo, L., \& Vintimilla, M. (2010). Pathology of bovine coccidiosis in Venezuela: A review. Rev. Electron. Vet ., 11 (7), 1-39.

Tasawar, Z., Naz, F., Lashari, M. H., \& Hayat, C. S. (2011). Prevalence of Ostertagia spp., in a sheep herd.Sarhad Journal of Agriculture. 27, 275-278.

Thrusfield, M. (2007). Veterinary Epidemiology. 3rd ed. Blackwell Science Ltd., Oxford. p624.

Tibi, K. N., \& Aphunu, A. (2010). Analysis of Cattle Market in Delta State: The Supply

Determinants. African Journal of General Agriculture, 6 (4), 199-203.

Tilak, C.N., Kazi, M.I., Nabila, I., Shyama, K.C., \& Jamal, U.B. (2016). Assessment of the

Prevalence of Gastrointestinal Parasitic Infections of Cattle in Hilly Areas of Bangladesh. World Scientific News, 59, 74-84

Tshering, G., \& Dorji, N. (2013). Prevalence of gastrointestinal parasites in free-range cattle; a case study in haa district, Bhutan. Journal of Animal Health and Production. 1(4): 36-37

William, J.C., \& Loyacano, A.F. (2012). Internal Parasites of Cattle in Louisiana and the Other

Southern States. Research Information Sheet LSU, Ag Centre Research and Extension, 212.

(www.rcv.ac.uk/review/Parasitology/Flotation fluid/General.htm accessed 26/04/2017).

Yuguda, A.M., Samaila, A.B., \& Panda S, M. (2018). Gastrointestinal helminths of slaughtered

cattle in Bauchi Central Abattoir, Bauchi State, Nigeria. GSC Biological and Pharmaceutical

Sciences , 4(02), 058-065.https://doi.org/10.30574/gscbps.2018.4.2.0036

TABLE 1. Demographic characteristics of agro-pastoral cattle sampled in Ibarapa central and north LGA, Oyo State, Nigeria

\begin{tabular}{llll}
\hline & aOR $^{+}$ & $\mathbf{9 5 \%} \mathbf{C I}$ & P-value \\
\hline Breed & 0.5 & $0.3-0.7$ & $0.001^{*}$ \\
Age & 0.5 & $0.3-0.7$ & $<0.001^{*}$ \\
BCS & 2.3 & $1.5-3.7$ & $<0.001^{*}$ \\
Herd size & 0.6 & $0.4-0.9$ & $0.004^{*}$ \\
\hline
\end{tabular}

${ }^{+}$Body condition score

TABLE 2. The overall prevalence of gastrointestinal parasites in agro-pastoral cattle in Ibarapa central and north LGA, Oyo State, Nigeria $(\mathrm{N}=377)$.

\begin{tabular}{lll}
\hline Description & No. of infected samples & Prevalence $\mathbf{( \% )}$ \\
\hline Cattle herds & 36 of 39 & 92.3 \\
Individual cattle & 219 & 58.1 \\
Helminths & & \\
Strongyles spp & 30 & 8.0 \\
Neoascaris spp & 38 & 10.1
\end{tabular}




\begin{tabular}{lll}
\hline Description & No. of infected samples & Prevalence (\%) \\
\hline Nematodirus spp & 11 & 2.9 \\
Strongyloides spp & 8 & 2.1 \\
Schistosoma spp & 10 & 2.7 \\
Paraphistomum spp & 23 & 6.1 \\
Taenid spp & 29 & 7.7 \\
Monienza spp & 11 & 2.9 \\
Protozoan & & \\
Eimeria spp & 155 & 41.1 \\
\hline
\end{tabular}

TABLE 3. Gastrointestinal parasite infection in agro-pastoral cattle by demographic distribution in Ibarapa central and north LGA, Oyo State

\begin{tabular}{|c|c|c|c|c|c|}
\hline & Variables & No. examined & No. infected (\%) & $\mathrm{OR}^{+}(95 \% \mathrm{CI})$ & P-value \\
\hline & White Fulani & 329 & $207(63)$ & Ref. & \\
\hline \multirow[t]{3}{*}{ Breed } & Bokolo & 18 & $4(22.2)$ & $0.2(0.04-0.6)$ & $0.002^{*}$ \\
\hline & Cross breed & 30 & $8(26.7)$ & $0.2(0.1-0.5)$ & $<0.001^{*}$ \\
\hline & {$[?] 2$ years } & 42 & $32(76.2)$ & Ref & \\
\hline \multirow[t]{3}{*}{ Age } & $3-5 y r s$ & 166 & $97(58.4)$ & $0.4(0.2-1.0)$ & $0.05^{*}$ \\
\hline & $>5 \mathrm{yrs}$ & 169 & $90(53.3)$ & $0.4(0.2-0.8)$ & $0.01^{*}$ \\
\hline & Lean & 13 & $12(92.3)$ & Ref & \\
\hline \multirow[t]{2}{*}{$\mathrm{BCS}^{++}$} & Moderate & 113 & $42(38.1)$ & $0.05(0.001-0.4)$ & $<0.001^{*}$ \\
\hline & Good & 251 & $165(66.5)$ & $0.2(0.004-1.1)$ & 0.1 \\
\hline \multirow[t]{3}{*}{ Sex } & Male & 30 & $17(56.7)$ & Ref & \\
\hline & Female & 347 & $202(58.2)$ & $1.1(0.5-2.4)$ & 1.0 \\
\hline & $1-30$ & 56 & $48(85.7)$ & Ref & \\
\hline \multirow[t]{3}{*}{ Herd size } & $31-50$ & 211 & $106(50.2)$ & $0.2(0.1-0.4)$ & $<0.001^{*}$ \\
\hline & $>50$ & 110 & $65(59.1)$ & $0.2(0.1-0.6)$ & $0.001^{*}$ \\
\hline & Total & 377 & $219(100)$ & & \\
\hline
\end{tabular}

*Significant at p[?]0.05, + Odds Ratio,${ }^{++}$Body condition score

TABLE 4. GIP (Nematodes) load enumeration based on breed, sex, age and BCS in agro-pastoral cattle herds in Ibarapa central and north LGA, Oyo State, Nigeria

\begin{tabular}{|c|c|c|c|c|c|c|c|c|}
\hline Variable & Category & $\mathbf{N}^{+}$ & Nematodes & Nematodes & Nematodes & Nematodes & Nematodes & Nema \\
\hline & & & Strongyles & Strongyles & & Neoascaris & Neoascaris & \\
\hline & & & No inf $++(\%)$ & OR $(95 \% \mathrm{CI})$ & $\mathbf{P}$ & No inf. (\%) & OR $(95 \% \mathrm{CI})$ & $\mathbf{P}$ \\
\hline \multirow[t]{3}{*}{ Breed } & White F & 329 & $28(93.3)$ & $2.6(0.3-143.9)$ & 2.6 & $36(94.7)$ & $2.1(0.3-89.7)$ & 0.3 \\
\hline & Bokolo & 18 & 0 & Ref & Boko & $1(2.6)$ & Ref & Boko \\
\hline & Cross & 30 & $2(6.7)$ & $2(0.1-159.6)$ & 1.0 & $1(2.6)$ & $0.6(0.01-48.7)$ & 1.0 \\
\hline \multirow[t]{3}{*}{ Sex } & Female & 347 & $28(93.3)$ & $1.2(0.3-11.2)$ & 1.0 & $35(92.1)$ & $1.0(0.3-5.5)$ & 1.0 \\
\hline & Male & 30 & $2(6.7)$ & Ref & Male & $3(7.9)$ & Ref & Male \\
\hline & $>5 \mathrm{yrs}$ & 169 & $13(43.3)$ & $1.6(0.6-4.9)$ & 0.5 & $10(26.3)$ & $1.1(0.4-3.2)$ & 1.0 \\
\hline \multirow[t]{3}{*}{ Age } & $3-5 y r s$ & 166 & $10(33.3$ & $1.2(0.4-4)$ & 0.9 & $20(52.6)$ & $2.3(0.9-6.2)$ & $0.05^{*}$ \\
\hline & {$[?] 2 \mathrm{yrs}$} & 42 & $7(23.3)$ & Ref & {$[?] 2 \mathrm{yrs}$} & $8(21.1)$ & Ref & {$[?] 2 \mathrm{y}$} \\
\hline & Good & 251 & $21(70)$ & $1.1(0.2-49)$ & 1.0 & $27(71.1)$ & $0.4(0.1-2.4)$ & 0.2 \\
\hline BCS & Moderate & 113 & $8(26.7)$ & $0.9(0.1-43.9)$ & 1.0 & $8(21.1)$ & $0.3(0.1-1.8)$ & 0.2 \\
\hline
\end{tabular}




\begin{tabular}{cllllllll}
\hline Variable & Category & $\mathbf{N}^{+}$ & Nematodes & Nematodes & Nematodes & Nematodes & Nematodes & Nema \\
\hline & Lean & 13 & $1(3.3)$ & Ref & Lean & $3(7.9)$ & Ref & Lean \\
\hline
\end{tabular}

${ }^{+}$Number of cattle sampled, ${ }^{++}$Number of infected cattle, ${ }^{\S}$ Nematodirus, ${ }^{\mathbb{I}}$ Strongyloides

*Significant at $\mathrm{p}[?] 0.05$

TABLE 5. GIP (Trematodes) load enumeration based on breed, sex, age and BCS in agro-pastoral cattle herds in Ibarapa central and north LGA, Oyo State, Nigeria

\begin{tabular}{|c|c|c|c|c|c|c|c|c|}
\hline Variable & Category & $\mathbf{N}^{+}$ & Trematode & Trematode & Trematode & Trematode & Trematode & \\
\hline & & & Schistosoma & Schistosoma & Schistosoma & Paraphistomum & Paraphistomum & 1 \\
\hline & & & No inf. (\%) & OR $(95 \% \mathrm{CI})$ & $\mathbf{P}$ & No inf ${ }^{++}(\%)$ & OR $(95 \% \mathrm{CI})$ & $\mathbf{P}$ \\
\hline \multirow[t]{3}{*}{ Breed } & White F & 329 & $10(100)$ & $1.4(0.2-84$ & 1.0 & $22(95.7)$ & $2.0(0.2-112)$ & 1.0 \\
\hline & Bokolo & 18 & 0 & $\mathrm{NA}$ & 0.8 & Ref & Ref & \\
\hline & Cross & 30 & 0 & Ref & Cross & $1(4.3)$ & $1.0(0.01-102.6)$ & 1.0 \\
\hline \multirow[t]{3}{*}{ Sex } & Female & 347 & 9 & $0.8(0.1-35)$ & 1.0 & $13(87)$ & $0.4(0.1-2.04)$ & 0 \\
\hline & Male & 30 & 1 & Ref & Male & $3(13)$ & Ref & \\
\hline & $>5 \mathrm{yrs}$ & 169 & $5(50)$ & $2.1(0.3-22.7)$ & 0.4 & $7(34.8)$ & $1.0(0.3-3.6)$ & \\
\hline \multirow[t]{3}{*}{ Age } & $3-5 y r s$ & 166 & $3(30)$ & $1.3(0.2-15.6)$ & 1.0 & $9(39.1)$ & $1.3(0.4-4.6)$ & 0 \\
\hline & [?]2yrs & 42 & $2(20)$ & Ref & [?]2yrs & $6(26.1)$ & Ref & \\
\hline & Good & 251 & $6(60)$ & $0.1(0.02-1.5)$ & 0.1 & $15(65.2)$ & $0.2(0.1-1.3)$ & \\
\hline \multirow[t]{2}{*}{ BCS } & Moderate & 113 & $2(20)$ & $0.1(0.01-1.6)$ & 0.1 & $5(21.7)$ & $0.2(0.03-1.2)$ & 0.1 \\
\hline & Lean & 13 & $2(20)$ & Ref & Lean & $3(13.0)$ & Ref & \\
\hline
\end{tabular}

${ }^{+}$Number of cattle sampled, ${ }^{++}$Number of infected cattle

*Significant at $\mathrm{p}[?] 0.05$

TABLE 6. GIP (Cestodes) load enumeration based on breed, sex, age and BCS in agro-pastoral cattle herds in Ibarapa central and north LGA, Oyo State, Nigeria

\begin{tabular}{|c|c|c|c|c|c|c|c|c|}
\hline Variable & Category & $\mathbf{N}^{+}$ & Cestodes & Cestodes & Cestodes & Cestodes & Cestodes & Cestor \\
\hline & & & Taenid spp & Taenid spp & Taenid spp & Moniezia & Moniezia & Moni \\
\hline & & & No inf $++(\%)$ & OR $(95 \% \mathrm{CI})$ & $\mathbf{P}$ & No inf. (\%) & OR $(95 \% \mathrm{CI})$ & $\mathbf{P}$ \\
\hline \multirow[t]{3}{*}{ Breed } & White F & 329 & $26(89.7)$ & $2.5(0.4-105.5)$ & 0.6 & 11(100) & $1(0.1-56.3)$ & 1.0 \\
\hline & Bokolo & 18 & $2(6.9)$ & $3.5(0.2-221.1)$ & 0.6 & 0 & Ref & Cross \\
\hline & Cross & 30 & $1(3.5)$ & Ref & Cross & 0 & NA & 1.0 \\
\hline \multirow[t]{3}{*}{ Sex } & Female & 347 & $28(96.5)$ & $2.5(0.4-107.6)$ & 0.6 & $11(100)$ & $1.5(0.2-87)$ & 1.0 \\
\hline & Male & 30 & $1(3.5)$ & Ref & Male & 0 & Ref & Male \\
\hline & $>5 \mathrm{yrs}$ & 169 & $7(24.1)$ & $2.0(0.5-12.2)$ & 0.5 & $6(54.5)$ & $8(0.8-482.5)$ & 0.1 \\
\hline \multirow[t]{3}{*}{ Age } & $3-5 y r s$ & 166 & $19(65.5)$ & $6(1.7-32.14)$ & $0.02^{*}$ & $5(45.5)$ & $6.8(0.6-418.6)$ & 0.2 \\
\hline & {$[?] 2$} & 42 & $3(10.4)$ & Ref & {$[?] 2$} & 0 & Ref & {$[?] 2$} \\
\hline & Good & 251 & $24(82.8)$ & $1.3(0.2-56.5)$ & 1.0 & $8(72.7)$ & $0.7(0.1-40.7)$ & \\
\hline \multirow[t]{2}{*}{ BCS } & Moderate & 113 & $4(13.8)$ & $0.4(0.04-23.5)$ & 0.9 & $3(27.3)$ & $0.6(0.03-39.9)$ & 1.0 \\
\hline & Lean & 13 & $1(3.5)$ & Ref & Lean & 0 & Ref & Lean \\
\hline
\end{tabular}

\footnotetext{
${ }^{+}$Number of cattle sampled, ${ }^{++}$Number of infected cattle
} 
*Significant at p[?]0.05

TABLE 7. GIP (Protozoan) load enumeration based on breed, sex, age and BCS in agro-pastoral cattle herds in Ibarapa central and north LGA, Oyo State, Nigeria

\begin{tabular}{|c|c|c|c|c|c|}
\hline Variable & Category & $\mathbf{N}^{+}$ & Protozoan & Protozoan & Protozoan \\
\hline & & & Eimeria & Eimeria & Eimeria \\
\hline & & & No inf $^{++}(\%)$ & OR $(95 \% \mathrm{CI})$ & $\mathbf{P}$ \\
\hline \multirow{3}{*}{ Breed } & White F & 329 & $147(94.8)$ & $4(1.1-22.1)$ & $0.03^{*}$ \\
\hline & Bokolo & 18 & $3(1.5)$ & $1(0.2-7.4)$ & 1.0 \\
\hline & Cross & 30 & $5(3.2)$ & Ref & Cross \\
\hline \multirow[t]{3}{*}{ Sex } & Female & 347 & $141(91)$ & $0.8(0.4-1.8)$ & 0.7 \\
\hline & Male & 30 & $14(9)$ & Ref & Male \\
\hline & $>5 \mathrm{yrs}$ & 169 & $74(47.8)$ & $3.6(2.1-6.5)$ & $0.000^{*}$ \\
\hline \multirow[t]{3}{*}{ Age } & $3-5 y r s$ & 166 & $56(36.1)$ & $2.4(1.4-4.3)$ & $0.002^{*}$ \\
\hline & [?]2yrs & 142 & $25(16.1)$ & Ref & {$[?] 2 \mathrm{yrs}$} \\
\hline & Good & 251 & $118(76.1)$ & $0.4(0.1-1.5)$ & 0.2 \\
\hline \multirow[t]{2}{*}{$\mathrm{BCS}$} & Moderate & 113 & $28(18.1)$ & $0.2(0.03-0.6)$ & $0.004^{*}$ \\
\hline & Lean & 13 & $9(5.8)$ & Ref & Lean \\
\hline
\end{tabular}

${ }^{+}$Number of cattle sampled, ${ }^{++}$Number of infected cattle

*Significant at p[?]0.05

TABLE 8. Predictors of Gastrointestinal parasite infection in agro-pastoral cattle herds in Ibarapa central and north LGA, Oyo State, Nigeria

\begin{tabular}{llll}
\hline & aOR $^{+}$ & $\mathbf{9 5 \%}$ CI & P-value \\
\hline Breed & 0.5 & $0.3-0.7$ & $0.001^{*}$ \\
Age & 0.5 & $0.3-0.7$ & $<0.001^{*}$ \\
BCS & 2.3 & $1.5-3.7$ & $<0.001^{*}$ \\
Herd size & 0.6 & $0.4-0.9$ & $0.004^{*}$ \\
\hline
\end{tabular}

*Significant at p[?]0.05, ${ }^{+}$Adjusted Odds Ratio 